Syntax Fusion : Jurnal Nasional Indonesia

e-ISSN : 2775-4440

Vol. 1, No. 9, September 2021

\title{
UPAYA MENINGKATKAN PRESTASI BELAJAR MATEMATIKA DENGAN MENGGUNAKAN ALAT PERAGA PADA SISWA KELAS III SD NEGERI TELUK BETUNG
}

\section{Merida}

SD Negeri 1 Teluk Betung

Email: merida.s.pdsd@gmail.com

\begin{abstract}
Abstrak
Tujuan dari penelitian ini adalah untuk mengetahui peningkatan nilai belajar matematika siswa kelas III menggunakan alat peraga di SD Negeri Teluk Betung Karau Kuala Pelajaran 2017/2018. Bentuk penelitian tindakan kelas (PTK). Walaupun populasi penelitian yang digunakan dalam penelitian ini adalah siswa kelas III SDN Teluk Betung Kecamatan Kalauguara tahun pelajaran 2017/2018, namun jumlah populasinya adalah 21 siswa. Dalam pengumpulan data, metode yang digunakan adalah metode utama, meliputi metode tes, metode observasi, dan metode dokumen. Metode tes digunakan untuk mengetahui nilai belajar matematika siswa setelah menerima pengajaran pada periode pertama dan kedua, metode observasi digunakan untuk mengetahui status sekolah, status siswa pada periode pengajaran pertama dan kedua, dan metode kepustakaan digunakan untuk menentukan nama subjek penelitian. Untuk memeriksa keabsahan data digunakan triangulasi data dan triangulasi metode. Dalam proses analisis, peneliti harus menyadari tiga komponen. Ketiga komponen tersebut adalah: 1) reduksi data; 2) penyajian data, 3) penarikan kesimpulan atau verifikasi. Berdasarkan hasil dan pembahasan, nilai rata-rata nilai belajar matematika siswa Kelas III pada siklus I adalah 67, dan pada siklus II adalah 76. Dengan demikian, nilai rata-rata dari siklus I ke siklus II mengalami peningkatan. Siklus dua. Tingkat ketuntasan siswa pada siklus I sebesar 60,97\% (25 dari 41 siswa tuntas belajar), dan pada siklus II sebesar 97,6\% (40 dari 41 siswa tuntas belajar). Oleh karena itu, dari periode I ke periode II, ketuntasan belajar siswa mengalami peningkatan.
\end{abstract}

Kata Kunci: Prentasi Belajar, Matematika, Alat Peraga

\section{Pendahuluan}

Sekolah merupakan salah satu tempat berlangsungnya kegiatan pengajaran, dan 
pada umumnya pemerintah bertanggung jawab. Peran pemerintah dalam menjalankan sekolah adalah ikut menentukan sistem dan muatan pendidikan. Mengenai lamanya waktu seseorang mencapai kedewasaan, hal ini terlihat jelas dari pelaksanaan sekolah secara bertahap dan proses belajar mengajar secara klasikal. Dan isi dari pendidikan semacam ini dituangkan dalam bentuk kursus. Hal ini tentunya harus disesuaikan dengan kemajuan dan perkembangan masyarakat.

Di sekolah, kehadiran guru sangat penting. Hal ini dikarenakan jika di suatu sekolah tidak ada guru, maka proses pendidikan tidak dapat dilaksanakan atau dilaksanakan. Rencana pelajaran tidak akan ada artinya Hal itu tidak dicapai melalui adanya kegiatan. Untuk itu peran guru sangat menentukan, karena ia berfungsi sebagai pengelola pendidikan di kalangan siswa kelas. Menurut kehadirannya di sekolah, tugas utama guru adalah mengajar, dan setiap kali guru mengajar, harus disiapkan cara agar apa yang diajarkan kepada siswa mudah diterima dan dipahami.

Selain itu, dalam proses pengajaran, peran guru dalam memilih metode mana yang akan digunakan sangat penting. Hal ini dikarenakan tugas utama guru adalah menyampaikan materi pembelajaran kepada siswa, dengan harapan siswa dapat dengan mudah menerima dan memahami apa yang telah dipelajarinya. Mengingat metode adalah suatu cara dan fungsinya merupakan alat untuk mencapai suatu tujuan, maka semakin baik metode tersebut maka semakin efektif pula untuk mencapai tujuan tersebut. Dapat dikatakan bahwa jika guru memilih metode pengajaran yang benar dan mengikuti prosedur, siswa dapat menerima dan memahami dengan baik materi yang diajarkan oleh guru.

SDN Telok Betong Kecamatan Kalau Kuala terletak di Desa Telok Betong. Ada 21 siswa di kelas tiga, termasuk 11 laki-laki dan 10 perempuan. Peralatan meja dan kursi siswa, 22 meja per meja, total 22 kursi. Di kelas ketiga, sebuah meja ditempati oleh seorang siswa. Dalam proses pembelajaran, guru menerapkan RPP sesuai langkah-langkah berikut: kegiatan awal, kegiatan inti dan kegiatan akhir, metode dan strategi pembelajaran, serta penilaian; dalam proses pembelajaran mata pelajaran matematika pecahan di kelas III.

Melalui ceramah, guru menceritakan kegiatan sehari-hari sebelum berangkat ke sekolah di media dengan materi yang ditulis di papan tulis. Dalam kegiatan inti: guru menjelaskan materi untuk didengarkan oleh siswa. Guru mengadakan sesi tanya jawab, dan beberapa siswa belum bertanya. Pada kegiatan akhir: guru melakukan penilaian untuk mengetahui kemampuan belajar siswa, hasilnya sebagai berikut: Nilai tertinggi: 80; Nilai terendah: 50 Nilai rata-rata: 60

Fakta membuktikan bahwa efek belajar matematika Kelas III belum memuaskan. Melihat kenyataan di atas, proses pembelajaran yang berlangsung di kelas tidak sesuai dengan harapan guru, siswa, dan sekolah. Hal ini dikarenakan guru hanya membaca saat mengirimkan materi, sehingga membuat siswa merasa bosan.

Selain itu, guru hanya menggunakan ceramah dalam proses pembelajaran, sehingga memungkinkan siswa pasif, mengantuk atau bermain sendiri. Selain itu, guru memberikan 
materi tanpa alat peraga atau menggunakan media pembelajaran yang sesuai, sehingga siswa tidak dapat memahami materi yang diajarkan. Sehingga proses pembelajaran selama ini memiliki banyak kekurangan. Seperti yang telah disebutkan di atas, mengenai penggunaan metode yang monoton, media pembelajaran yang tidak sesuai, dan penyampaian materi yang tidak menarik minat siswa.

Setelah mengkaji proses pembelajaran yang telah berlangsung, telah dilaksanakan, dan dideskripsikan, masalahnya terletak pada guru sebagai penyaji materi. Permasalahan yang ada adalah sebagai berikut: Guru kurang menguasai bahan ajar dan belum mencapai tujuan pembelajaran, alat/media yang digunakan guru kurang tepat atau tidak sesuai, dan siswa pasif karena guru tidak menggunakan berbagai metode. saat memberikan materi, dan aktivitas anak-anak relatif rendah, karena aktivitas hanya berpusat pada guru.

Oleh karena itu, melihat hasil proses pembelajaran yang kurang memuaskan, maka peneliti akan mempelajari dan memperbaiki matematika jenis skor ketiga di masa yang akan datang. Sampai siswa kelas tiga memenuhi harapan. Melalui pembelajaran: prestasi akademik matematika siswa, lembar kehadiran siswa (absensi), catatan kegiatan siswa, dll.

Melihat kenyataan di atas, guru harus mampu memperbaiki sistem pembelajaran, selama ini pembelajaran tanpa menggunakan alat peraga belum menarik perhatian siswa sehingga menyebabkan prestasi belajar siswa rendah. Selain itu, dari banyak aspek, metode pembelajaran dengan menggunakan alat peraga dapat meningkatkan minat belajar siswa, sehingga mencapai hasil akademik yang memuaskan. Untuk memahami apakah penggunaan alat peraga dapat meningkatkan prestasi belajar matematika, maka perlu dilakukan penelitian.

\section{Metode Penelitian}

Tempat yang penulis jadikan pelaksanaan penelitian tindakan kelas ini adalah di SD Negeri Teluk Betung Kecamatan Karau Kuala. Tempat penelitian berlokasi di SD Negeri Teluk Betung Kecamatan Karau Kuala, dimana tempat ini sekaligus tempat penulis melaksanakan tugas mengajar.

1. Populasi

Populasi dalam penelitian ini adalah seluruh siswa kelas III SD Negeri Teluk Betung Kecamatan Karau Kuala sebanyak 21 siswa

2. Sampel.

Sampel yang penulis pergunakan dalam penelitian ini adalah seluruh siswa kelas III SD Negeri Teluk Betung Kecamatan Karau Kuala yang terdiri 21 siswa.

Dalam penelitian ini menggunakan model yang didasarkan atas konsep pokok bahwa penelitian tindakan terdiri dari empat komponen pokok yang juga menunjukkan langkah pelaksanaan penelitian, yaitu : 1. Perencanaan atau Planning 2. Tindakan atau Acting 3. Pengamatan atau Observasing dan Refleksi atau Reflekting (Arikunto, 2002: 83) 
Merida

Secara lebih rinci, dapat digambarkan dengan skema pelaksanaan prosedur penelitian tindakan kelas berikut ini :

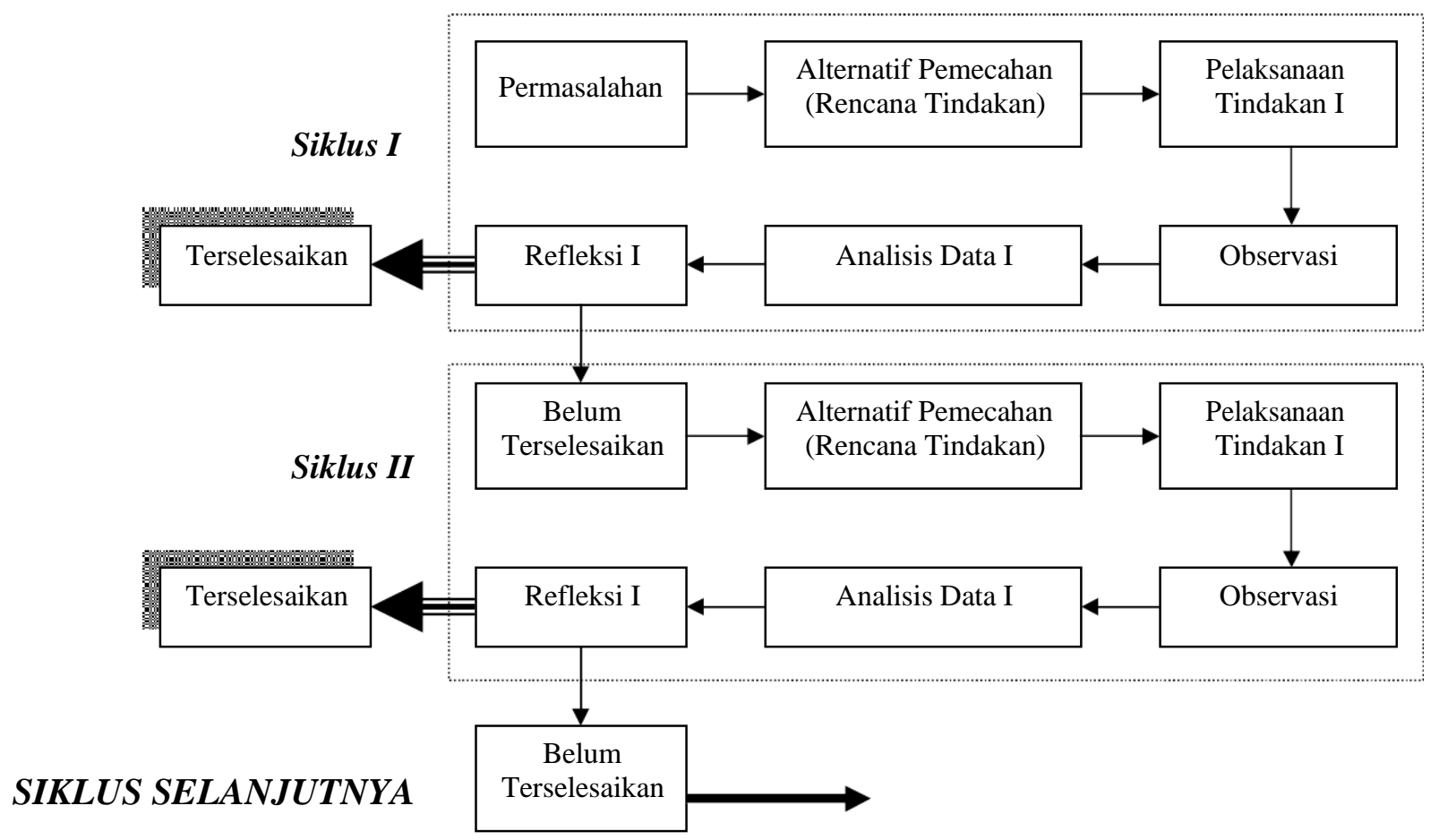




\section{Hasil Dan Pembahasan}

\section{A. Hasil Penelitian}

\section{Deskripsi Prestasi Belajar Sebelum Pembelajaran Siklus I}

Dari hasil ulangan harian sebelum kegiatan perbaikan pembelajaran dapat diketahui hasilnya sebagai berikut :

Dari 21 siswa yang mengikuti pembelajaran matematika dapat diketahui nilai tertinggi yang diraih siswa adalah 80 dan yang terendah adaalah 50, dengan rata - rata hasil ulangan harian adalah 61. Adapun data lengkap peroleh nilai oleh siswa pada siklus I dapat dilihat pada table berikut :

Tabel 1 Rekapitulasi Hasil Belajar Sebelum Siklus I

\begin{tabular}{cccc}
\hline Nomer & Nilai & frekuensi & Prosentase \\
\hline 1 & 50 & 11 & $26,8 \%$ \\
\hline 2 & 60 & 16 & $39 \%$ \\
\hline 3 & 70 & 12 & $29,3 \%$ \\
\hline 4 & 80 & 2 & $4,9 \%$ \\
\hline & Jumlah & 41 & $100 \%$ \\
\hline
\end{tabular}

Histogram Prestasi Belajar Matematika Sebelum Siklus I

Keterangan X menyatakan jumlah siswa dan Y menyatakan Nilai siswa

\section{Pelaksanaan Pembelajaran Siklus I}

a. Paparan Data Hasil Penelitian

Setelah selesainya siklus 1 maka siswa dites dengan soal formatif dengan hasil test sebagai berikut :

Dari 21 siswa yang mengikuti pembelajaran matematika dapat diketahui nilai tertinggi yang diraih siswa adalah 80 dan yang terendah adalah 50, dengan rata - rata hasil ulangan test formatif adalah 67. Adapun data lengkap peroleh nilai oleh siswa pada siklus I dapat dilihat pada table berikut :

Rekapitulasi Hasil Belajar Pada Siklus I

\begin{tabular}{ccrc}
\hline Nomor & Nilai & frekuensi & Prosentase \\
\hline 1 & 50 & 1 & $4.88 \%$ \\
\hline 2 & 60 & 7 & $34,15 \%$ \\
\hline 3 & 70 & 9 & $43,90 \%$ \\
\hline 4 & 80 & 4 & $17,07 \%$ \\
\hline
\end{tabular}




Jumlah $\quad 21 \quad 100 \%$

Dari data dalam table 2 di atas bila dibuat dalam bentuk diagram sebagai berikut: $\mathrm{X}$

8

6

5

4

3

2

1

0

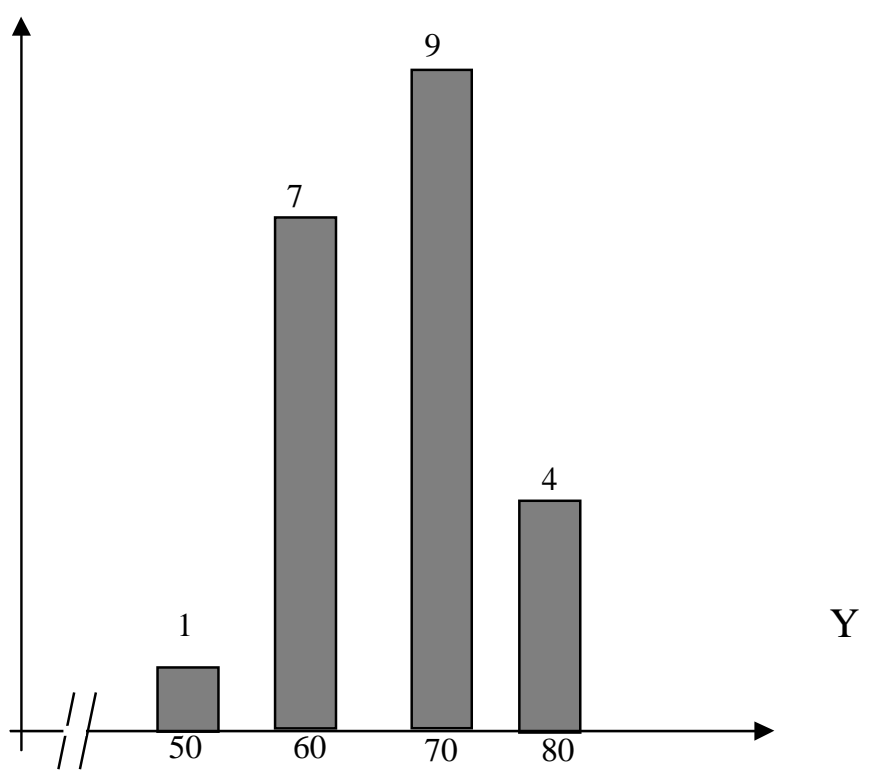

Keterangan X menyatakan jumlah siswa dan Y menyatakan Nilai siswa

b. Kendala yang Muncul Pada Pembelajaran Siklus I

Masalah yang muncul dalam pembelajaran siklus 1 dapat dilihat oleh peneliti saat berlangsungnya proses pembelajaran dan hasil test formatif yang dilakukan setelah selesai pembelajaran. Adapun masalah yang timbul dalam pembelajaran siklus 1 antara lain:

1) Keaktifan dalam mengikuti pembelajaran dirasa kurang

2) Kemampuan anak untuk menyelesaikan tugas atau ulangan soal cerita kurang karena kemampuan anak dalam memahami kata-kata dirasa kurang apalagi dengan model soal yang memadukan berbagai jenis bahan contoh yang berbeda-beda.

3) Ketrampilan bertanya dirasakan kurang karena anak masih sukar memahami konsep bilangan pencahan.

4) Kemampuan mengemukakan pendapat masih dirasa kurang baik.

c. Implementasi Penyelesaian Permasalahan Siklus I

Rancangan Strategi penyelesaian masalah dan paparan langkah implementasi penyelesaian dalam siklus 1

1) Untuk mengaktifkan anak - anak yang kurang aktif dapat dilakukan dalam pembelajaran siklus II dengan menyusun lembar kerja yang membuat setiap anggota kelompok menjadi aktif.

2) Untuk meningkatkan kemampuan anak menyelesaikan soal cerita maka pada siklus 2 dibuat dengan variasi soal yang mudah dipahami oleh anak agar anak mampu 
memahami soal cerita dengan baik

3) Agar anak dapat memiliki kemampuan bertanya dengan baik maka pada siklus 2 guru akan membuat lembar kerja yang memungkinkan anak lebih aktif lagi. Selain itu pada siklus 1 jumlah kelompok terasa terlalu banyak yakni 6 orang sehingga ada sebagian anak kurang terlibat dalam proses diskusi dalam kelompoknya, maka pada siklus kedua jumlah anggota kelompok diperkecil menjadi 4 orang siswa dan setiap kelompok diberi kesempatan untuk menyampaikan hasil diskusinya di depan kelas.

4) Agar dapat membangkitkan kemampuan mengemukakan pendapat siswa maka pada siklus 2 guru akan memberikan tugas dan pertanyaan pada siswa yang dirasa kurang aktif pada siklus 1 .

\section{Pelaksanaan Pembelajaran Siklus II}

a. Paparan Hasil Pembelajaran Siklus II

Setelah selesainya siklus 2 maka siswa dites dengan soal formatif dengan hasil test sebagai berikut :

Dari 21 siswa yang mengikuti pembelajaran matematika dapat diketahui nilai tertinggi yang diraih siswa adalah 90 dan yang terendah adaalah 60, dengan rata - rata hasil ulangan test formatif adalah 76. Adapun data lengkap peroleh nilai oleh siswa pada siklus I dapat dilihat pada table berikut :

Tabel 3 Rekapitulasi Hasil Belajar Pada Siklus II

\begin{tabular}{cccc}
\hline Nomer & Nilai & frekuensi & Prosentase \\
\hline 1 & 60 & 1 & $2.44 \%$ \\
\hline 2 & 70 & 8 & $41,46 \%$ \\
\hline 3 & 80 & 10 & $48,78 \%$ \\
\hline 4 & 90 & 2 & $7,32 \%$ \\
\hline & Jumlah & 21 & $100 \%$
\end{tabular}

Dari data dalam table 3 di atas bila dibuat dalam bentuk diagram sebagai berikut: 


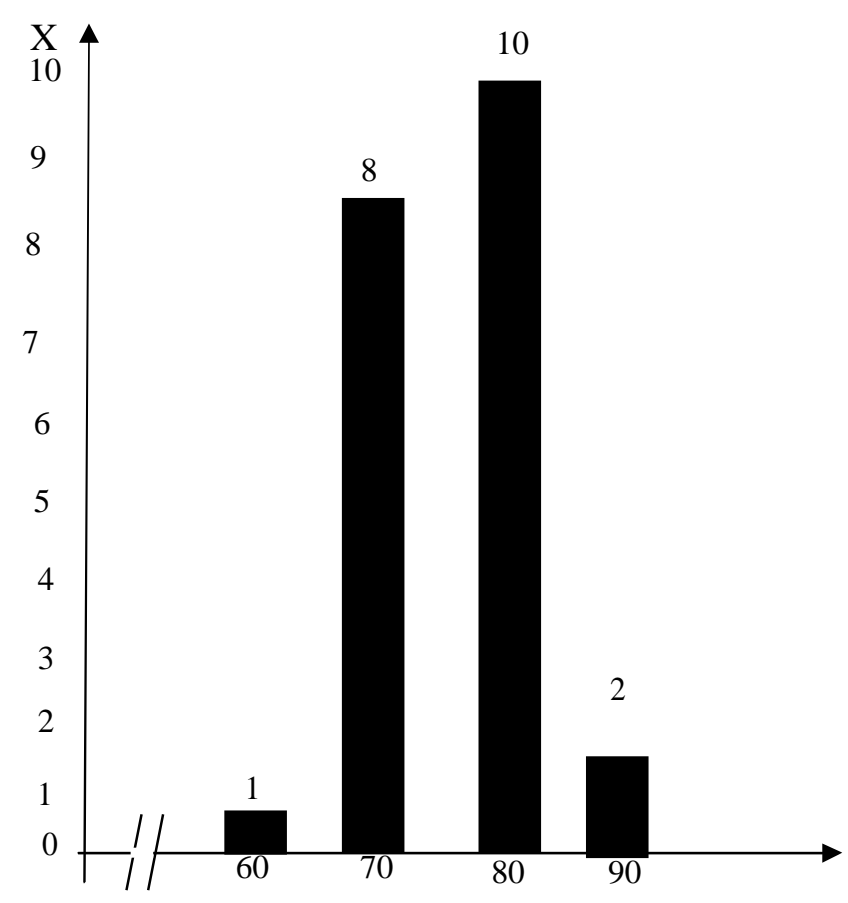

Histogram Prestasi Belajar Matematika pada Siklus II

Keterangan X menyatakan jumlah siswa dan Y menyatakan Nilai siswa

Sementara itu, siswa kelas III SD Negeri Teluk Betung Kecamatan Kuala Kalaw memiliki batas maksimal 65 siswa untuk menyelesaikan Mata Pelajaran Matematika (KKM), maka setelah siklus II diumumkan siswa yang telah menyelesaikan mata pelajaran matematika (KKM). pelajaran matematika akan menjadi 20 siswa dari 21 siswa. $(97,6 \%)$ karena tingkat penyelesaian kelas adalah 97,6\%. Dengan cara ini, dapat dikatakan bahwa siswa kelas 3 telah mencapai integritas kelas dengan cara klasik.

Pada pembelajaran siklus II permasalahan yang muncul tidak terlalu signifikan, artinya hampir semua anak mengikuti kurikulum dengan baik, dan semangat dalam proses belajar mengajar dan kegiatan bertanya kepada guru dimulai dengan baik. Mengenai kemampuan anak dalam memahami materi cerita, soal-soalnya ditingkatkan karena soalsoal diajukan dengan bahasa yang sederhana dan mengacu pada pengalaman sehari-hari siswa.

Karena masalah pada Siklus 2 tidak terlalu penting, tidak diperlukan langkah pemecahan masalah. Dalam hal ini perlu mengkomunikasikan saran kepada peneliti lain untuk meningkatkan kemampuan matematika anak dalam hal skor, yang dapat dilakukan melalui metode pembelajaran kelompok dengan menggunakan media tertentu.

Dari pembahasan diatas dapat dibuat suatu perbandingan antara sebelum Siklus I, Siklus I dan Siklus II pada tabel sebagai:

Tabel 4 : Perbandingan Prestasi Matematika Siswa Kelas III 


\begin{tabular}{llccc}
\hline \multirow{2}{*}{ Uo } & \multirow{3}{c}{ Uraian } & \multicolumn{3}{c}{ Frekuensi } \\
\cline { 3 - 5 } & & Sebelum Siklus & Siklus I & Siklus II \\
\hline \hline 1 & Nilai 50 & 5 siswa & 1 Siswa & - \\
\hline 2 & Nilai 60 & 8 siswa & 7 siswa & 1 siswa \\
\hline 3 & Nilai 70 & 6 siswa & 9 siswa & 8 siswa \\
\hline 3 & Nilai 80 & 2 siswa & 4 siswa & 10 siswa \\
\hline 4 & Nilai 90 & - siswa & - siswa & 2 siswa \\
\hline 5 & Nilai Rata - rata & 61 & 67 & 76 \\
\hline 6 & Siswa Tuntas & 8 siswa & 13 siswa & 20 siswa \\
\hline 7 & Prosentase Siswa Tuntas & $34,15 \%$ & $95,1 \%$ & $97,6 \%$ \\
\hline 8 & Siswa Tak Tuntas & 13 siswa & 8 siswa & 1 siswa \\
\hline 9 & Prosentase Siswa Tak & $61,9 \%$ & $38,1 \%$ & $4.7 \%$ \\
\hline
\end{tabular}

\section{B. Pembahasan}

\section{Pembahasan dari Setiap Siklus}

\section{a. Pembahasan dari Sebelum Siklus}

1) Rata - rata yang diperoleh siswa sebesar 61.

2) Siswa yang mendapatkan nilai 75 ke atas sebanyak 1 orang

3) Siswa yang mendapatkan nilai antara 60 sampai 74 sebanyak 14 orang

4) Siswa yang mendapatkan nilai kurang dari 60 sebanyak 6 orang

5) Siswa yang telah dinyatakan memiliki ketuntasan belajar (dengan nilai 65 ke atas ) sebanyak 7 orang dari jumlah 21 siswa atau 34,15\%, sedangkan anak yang belum tuntas sebanyak 14 orang dari jumlah 21 siswa atau 65,85\%.

\section{b. Pembahasan dari Siklus I}

1) Rata - rata yang diperoleh siswa sebesar 67.

2) Siswa yang mendapatkan nilai 75 ke atas sebanyak 4 orang

3) Siswa yang mendapatkan nilai antara 60 sampai 74 sebanyak 16 orang

4) Siswa yang mendapatkan nilai kurang dari 60 sebanyak 1 orang

5) Siswa yang telah dinyatakan memiliki ketuntasan belajar (dengan nilai 65 ke atas ) sebanyak 13 orang dari jumlah 21 siswa atau 60,97

$\%$, sedangkan anak yang belum tuntas sebanyak 8 orang dari jumlah 21 siswa atau 39,03\%.

\section{c. Pembahasan dari Siklus II}

1) Rata - rata yang diperoleh siswa sebesar 76.

2) Siswa yang mendapatkan nilai 75 ke atas sebanyak 12 orang 
Merida

3) Siswa yang mendapatkan nilai antara 60 sampai 74 sebanyak 9 orang

4) Siswa yang mendapatkan nilai kurang dari 60 sebanyak 0 orang

5) Siswa yang telah dinyatakan memiliki ketuntasan belajar (dengan nilai 65 ke atas ) sebanyak 20 orang dari jumlah 21 siswa atau 97,6\%, sedangkan anak yang belum tuntas sebanyak 1 orang dari jumlah 21 siswa atau $2,4 \%$.

\section{Pembahasan hasil Analisis Data}

Setelah alat peraga dipelajari dan diselesaikan, dilihat dari rata-rata kelas, nilai klasik dari nilai pre-test sebelum pembelajaran alat peraga memang kurang baik, terlihat bahwa rata-rata adalah 67. Selain itu, jika Anda cermati. Perhatikan perhitungan di atas, terlihat ada 21 siswa, sebanyak 20 siswa atau sebanyak 97,6\% siswa kelas II telah mencapai nilai ujian prost lebih dari 65. Artinya dalam hal ketuntasan belajar (standar ketuntasan belajar digunakan di sini, jika siswa mendapat nilai 65 atau lebih tinggi). Di sisi lain, dapat dilihat bahwa penggunaan alat peraga untuk pembelajaran mendorong siswa untuk belajar lebih giat, sehingga hanya satu siswa atau 2,4\% siswa yang mendapat nilai kurang dari 65 pada nilai ulangan harian.

Dari uraian di atas dapat disimpulkan bahwa penggunaan alat peraga pada pembelajaran matematika kelas III SD Negeri Teluk Betung Kecamatan Kuala Guara Tahun 2017/2018 dapat meningkatkan hasil belajar.

\section{Kesimpulan}

Berdasarkan hasil dan pembahasan dapat diketahui bahwa nilai rata-rata skor belajar matematika siswa kelas III pada siklus I adalah 67, dan pada siklus II adalah 76, sehingga nilai rata-rata dari siklus I ke siklus II memiliki ditingkatkan. Siklus dua. Tingkat ketuntasan siswa pada siklus I sebesar 60,97\% (25 siswa tuntas seluruhnya 41 siswa), dan pada siklus II sebesar 97,6\% (40 siswa tuntas seluruhnya 41 siswa). Oleh karena itu, dari periode I ke periode II, ketuntasan belajar siswa mengalami peningkatan.

Berdasarkan keterangan di atas dapat ditarik kesimpulan sebagai berikut: Melalui alat peraga siswa dapat meningkatkan prestasi belajar matematika kelas III SD Negeri Teluk Betung Kecamatan Kalauguara Tahun Pelajaran 2017/2018. 
Upaya Meningkatkan Prestasi Belajar Matematika Dengan Menggunakan Alat Peraga

\section{Bibliografi}

Hamalik, 1992, Media Pendidikan, Bandung : Penerbit alumni.

Hartoyo, 1999. Evaluasi Hasil Belajar dan Pengajaran Remedial. Surakarta : FKIP UNS.

Muhibbin Syah, 2004. Psikologi Pendidikan dengan Pendekatan Baru. Bandung Remaja Rosda Karya

Nasution, 2003. Metode Research( Penelitian Ilmiah). Jakarta : Bumi Aksara. Nurdin dkk, 1999. Matematika untuk SD Kelas III , Bandung : Rosda Karya. Ngadino, 1986. Media Pendidikan. Jakarta : Bumi Aksara

Purwodarminto, 1990, Kamus Umum Bahasa Indonesia, Jakarta balai Pustaka Roijakkers, 1982, Mengajar dengan Sukses, Jakarta : Gramedia.

Sulistriyo, 1987. Strategi Belajar Mengajar. Surakarta : UNS Press.

Sutopo, 1987. Psikologi Belajar. Surakarta: Sekolah Guru Pendidikan Luar Biasa.

Sugiyono, 2002. Metode Penelitian Administrasi. Bandung : Alfabeta

Suharsimi Arikunto, 2002. Prosedur Penelitian, Suatu Pendekatan Praktek. Jakarta : Renika Cipta.

Sumadi Suryabrata, 2003. Metodologi Penelitian. Jakarta : Raja Grafindo Persada. Sutrisno Hadi, 2002. Statistik Jilid 3. Yogyakarta: Andi Offset

UU RI No. 20, 2003. Sistem Pendidikan Nasional. Jakarta: DPR RI.

Winkel, 2005. Psikologi Pengajaran. Yogyakarta : Media Abadi.

Wahyudin; Sudrajat, 2004. Ensiklopedi Matematika untuk SLTP. Jakarta : Samudra Berlian. 